\title{
Tolerating herbivory: does the plant care if the herbivore has a backbone?
}

Post-print/Accepted manuscript

Peter M. Kotanen

Joshua P. Rosenthal

Kotanen, P. \& Rosenthal, J. Evolutionary Ecology (2000) 14: 537. doi:10.1023/A:1010862201331

The final publication is available at Springer via http://dx.doi.org/10.1023/A:1010862201331

\section{HOW TO CITE TSPACE ITEMS}

\begin{abstract}
Always cite the published version, so the author(s) will receive recognition through services that track citation counts, e.g. Scopus. If you need to cite the page number of the TSpace version (original manuscript or accepted manuscript) because you cannot access the published version, then cite the TSpace version in addition to the published version using the permanent URI (handle) found on the record page.
\end{abstract}


January 8, 2001

\title{
OPINION
}

\section{Tolerating herbivory: does the plant care if the herbivore has a backbone?}

\author{
P.M. KOTANEN* \\ Department of Botany, University of Toronto at Mississauga, 3359 Mississauga Road North, \\ Mississauga, ON, L5L 1C6, Canada
}

AND

J.P. ROSENTHAL

Fogarty International Center, National Institutes of Health, Building 31, Room B2C39, Bethesda, MD 20892-2220, USA

(*author for correspondence, e-mail: pkotanen@credit.erin.utoronto.ca; tel: 905-828-5365; fax: 905-828-3792)

Key words: arthropod, compensation, damage, herbivory, insect, invertebrate, tolerance, vertebrate 
Abstract. Differences in size-related ecology and behaviour between vertebrate and invertebrate herbivores lead to differences in the rates, tissue specificity, and spatial distribution of their damage, as well as in their indirect effects. As a result, many features of tolerance to herbivory by these groups also may differ. Tolerating vertebrate herbivory may demand the ability to tolerate sporadic non-specific impacts; this may be achieved by broad responses promoting regrowth and resource acquisition. In contrast, the diversity of different types of invertebrate damage seems likely to demand a correspondingly great variety of responses. These conclusions suggest that tolerance to invertebrates may involve a broader set of responses than tolerance to vertebrates; conversely, the greater specificity of these responses may make it more difficult for arthropodtolerant plants to achieve cross-tolerance to other types of damage. 


\section{Introduction}

Tolerance to herbivory has attracted much attention from both vertebrate and invertebrate ecologists. Tolerance has long been known to play a significant role in mammalian grazing systems (e.g., McNaughton 1979; Mack and Thompson 1982; Detling and Painter 1983; McNaughton 1984; Coughenour 1985; Milchunas et al. 1988). Similarly, tolerance to invertebrate herbivory is important in both agricultural and natural systems (e.g., Painter 1958; van der Meijden et al. 1988; Trumble et al. 1993). Several recent reviews have summarized the ecology and evolution of tolerance, and indicate that considerable progress has been made in both empirical and theoretical arenas (Rosenthal and Kotanen 1994; Strauss and Agrawal 1999; Stowe et al. 2000).

In this paper, we contrast tolerance to vertebrates with tolerance to invertebrates. We propose that tolerance to vertebrates and invertebrates are overlapping but distinct syndromes. Vertebrates and invertebrates often damage plants in functionally distinct ways; as a result, mechanisms of tolerance to these sources of damage also differ. In particular, we suggest that tolerance to invertebrates involves a more diverse set of responses than tolerance to vertebrates, while the greater specificity of these responses may make it more difficult for arthropod-tolerant plants to achieve cross-tolerance to other types of damage.

\section{Differences between vertebrate and invertebrate herbivory}

Herbivory by vertebrates and invertebrates shares many features. Both produce structural damage, remove tissue, nutrients and carbohydrates, and ultimately can reduce resource acquisition, competitive ability, growth, and reproduction (e.g., Crawley 1983; Hendrix 1988; Louda et al. 1990; Marquis 1992; Crawley 1997). So what are the key differences between these kinds of damage? We consider four general issues that can differ greatly between vertebrate and 
invertebrate herbivory: rates of damage, tissue specificity, distribution of damage, and indirect effects. Most of these differences ultimately are consequences of differences in body size between vertebrates and invertebrates, which, through evolution, result in many differences in their ecology, physiology, and behaviour (Table 1).

\section{Rates of Damage}

Rates of tissue removal can differ significantly between vertebrate and invertebrate herbivores. Crawley (1989) argues that vertebrates more commonly produce severe impacts on plant populations than do insects, and therefore are generally more important in the evolution of plant responses; other authorities disagree (e.g., Tscharntke and Greiler 1995). We do not directly address that issue; rather, we argue that these groups of herbivores tend to remove tissue according to different schedules, which may be as important as overall quantities of tissue loss to the evolution of tolerance.

Damage by vertebrates is often rather sudden and severe, reflecting their large body size, relative to plant size; a single bite may remove more tissue than even an extended insect attack. Episodes of damage to any given plant usually are sporadic, even in heavily-grazed systems: attacks may be separated by days, or even years, because grazing is patchy (Varnamkhasti et al. 1995) or because plants occur in temporary refuges such as areas near cattle faeces (Harper 1977; Vallentine 1990). In contrast, most invertebrate attacks involve the gradual removal of small amounts of tissue over prolonged periods of contact. For example, individual gall forming wasps frequently develop and feed on host plant stems or leaves over a period of months (Fay et al. 1996; Abrahamson and Weis 1997), as compared to vertebrate attacks that may last a few minutes or even seconds. As a result, plants are challenged by a continuous drain on resources at multiple damage 
points, rather than discrete episodes of damage. These slower rates of damage by invertebrates may allow greater remobilization of nutrients (Baldwin and Preston 1999) from damaged tissues for regrowth, defense, or other functions than does damage by vertebrates.

Exceptions exist to these rules of thumb. For instance, insects attacking seeds or seedlings may have large body sizes relative to their host plants, and correspondingly large and rapid effects (Mattson et al. 1988). As another example, outbreaking or migratory generalist insects that reach high densities may in many ways act like vertebrates. For example, insects such as spruce budworms, gypsy moths, locusts, spider mites, and leafcutter ants may remove large amounts of tissue in short period. Damage by such insects may collectively rival that of grazing vertebrates (Tscharntke and Greiler 1995).

\section{Tissue specificity}

Tissue specificity generally is much greater for species of invertebrates than for vertebrates (Strong et al. 1984; Crawley 1989). In part, this is an evolutionary consequence of body size and metabolism, reflecting the demand of vertebrates for larger quantities of forage. As well, their large size relative to their food plants reduces the ability of vertebrates to specialize on particular plant organs or tissues, even though they may specialize at larger physical scales. Vertebrate diets routinely include a wide selection of available tissues: most vertebrate herbivores eat mixtures of leaves, stems, flowers, seeds, and occasionally below-ground organs. In contrast, there are arthropod species that specialize on almost every organ and tissue found in plants, including xylem sap, phloem sap, leaf parenchyma, root cortex, leaf epidermis and vascular cambium, with a corresponding range of effects (Bardner and Fletcher 1974; Strong et al. 1984; Mattson et al. 1988). For example, even within the single weevil genus, Apion, different species feed 
preferentially on flower buds, inflorescences, fruits and seeds, leaf buds, stems, and roots (Bernays and Chapman 1994).

The specificity of damage means that relatively minor loss of tissue biomass to some invertebrate feeders may have disproportionately large impacts on the host plant. For instance, gamete feeding by beetles can have a large impact on reproductive output in Isomeris arborea shrubs (Krupnick and Weis 1999). Moderate but repeated damage to apical meristems by caterpillars in fireweed can produce large lifetime effects on plant fitness (Doak 1992). Damage to vascular tissue and inflorescences by fewer than 2 larvae of stemboring lepidoptera can dramatically affect the yield of maize (Flynn and Reagan 1984; Rosenthal and Welter 1995), as can fewer than 5 stemboring weevils per stem on Piper spp. (Letourneu 1998).

The large differences in tissue specificity among vertebrates and invertebrates, combined with the diversity of the roles of those tissues in plant development make explicit comparisons of tolerance to these groups difficult. Reaction norms are increasingly seen as one of the best tools for analysis of tolerance (Stowe et al. 2000). However, one still needs to identify relevant damage measures. While naturally occurring herbivore pressure will continue to be useful for some comparative studies (e.g., Hulme 1996; Throop and Fay 1999), these cannot typically differentiate the relevant contributions of defense and tolerance to herbivore resistance (Tiffin and Inouye 2000). Highly derived tools such “economic injury levels” are useful for applied agricultural studies, but these are also challenged by comparisons among different herbivore guilds (Pedigo et al. 1986). It appears that physiologically-relevant measures of standardized tissue losses or specific nutrient losses (e.g., $\mathrm{N}$ or $\mathrm{C}$ ) will continue to be among our best means of such comparisons. 


\section{Distribution of damage}

Damage by both vertebrates and invertebrates rarely is distributed randomly; for example, damage by both groups often is concentrated on the more nutritious young growth (Crawley 1983, 1989; Coley and Barone 1996). Damage may be patchy for non-nutritional reasons as well, including microclimate, herd or aggregative behaviour, evasion of enemies, restricted mobility following colonization events, and chance (Crawley 1983, 1989; Trumble et al. 1993; Rosenthal and Welter 1995). Vertebrate and invertebrate herbivores may often produce different spatial distributions of damage, again reflecting differences in body size and their consequences. Vertebrates and mobile invertebrates seem likely to produce patchiness at a much larger spatial scale than sedentary or parasitic insects, which can produce patchy damage even within a single ramet (Crawley 1989; Trumble et al 1993; Tscharntke and Grieler 1995); however, such differences may be less pronounced than they superficially appear: the scale of a single vertebrate bite may not be so different from the damage produced by many insects, though it occurs over a much shorter interval.

Finally, beyond the actual damage site, invertebrate feeders such as sucking or galling insects may produce a physiological drain on nearby ramets of the same individual for extended periods (Marquis 1996; Abrahamson and Weis 1997). For vertebrate herbivores, extended continuous resource drains generally are limited to post-damage reallocation to support regrowth.

\section{Indirect effects}

One final difference between vertebrates and invertebrates is the potential for positive indirect effects on plants. Benefits of this type can reduce the costs of damage by enhancing compensatory growth. Such indirect effects are not uncommon in systems intensely exploited by vertebrates, where herbivory can increase light availability, conserve water, lead to nutrient additions, reduce 
soil C:N ratio, remove competitors, and reduce fire frequency, though negative effects also are possible (McNaughton 1979; Cargill and Jefferies 1984a,b; Bazely and Jefferies 1989; Hobbs 1996). Such environmental modifications may be less common for invertebrates, though they can occur when herbivores and their host plants are sufficiently abundant to compensate for their small individual size and relatively restricted diet. For example, invertebrates can increase soil fertility by depositing faeces, by causing premature abscission of nitrogen-rich leaves, and by altering the abundance of keystone plant species (Trumble et al. 1993; Brown 1994; Maron and Jefferies 1999). However, the most important indirect effect of invertebrate herbivory may be negative: the transmission of diseases. At least 200 plant diseases, including viral, bacterial, mycoplasmal, rickettsial and fungal pathogens, have invertebrate vectors; transmission of these diseases occurs through opportunistic infections at plant damage points, passive transmission by herbivores that harbour hitchhiking pathogens, and active inoculation during feeding (Mattson et al. 1988; Borror et al. 1989; Nyvall 1989). The importance of arthropod-borne diseases means that disease resistance may also be an important mechanism of tolerance to herbivory.

\section{Summary of key differences}

Vertebrate and invertebrate herbivory often differ in functionally significant ways. Insect damage is very diverse in both type and spatial distribution. Damage may be chronic and generalized across plant tissues or highly focused on specific tissues. The most important indirect effect of invertebrate feeding may be disease transmission. In contrast, vertebrate damage may be more characterized by large but sporadic and nonspecific damage of tissues. Vertebrate damage also may be patchy across a larger range of spatial scales, and may be more likely to have at least some positive side-effects. There are many exceptions to these generalizations; in particular, highly 
abundant or aggregating polyphagous chewing insects may in many ways have impacts like those of vertebrates.

\section{Plant responses}

If damage by vertebrates and invertebrates differs, what consequences does this have for the kinds of traits that confer tolerance to herbivory? . Responses may differ between different groups of plants; for example, woody plants may be less tolerant of defoliation than herbs (Obeso 1993). Nonetheless, anything that promotes compensatory regrowth (e.g., increased photosynthetic rates, increased uptake of nutrients and water) is likely to increase tolerance to both insect and vertebrate damage. But can any generalizations be made about differences as well as similarities?

\section{Responses to vertebrates}

Different vertebrates prefer different plant parts; however, since most vertebrate grazers and browsers remove plant tissue in bulk, tolerance to these herbivores often may be less idiosyncratic than for invertebrates, and more linked to generalized traits that allow rapid regrowth following damage. Examples of such traits include stored reserves, flexible allocation, numerous dormant meristems, protected or basal meristems, well-developed clonality, and intrinsically high rates of leaf turnover (McNaughton 1979, 1984; Coughenour 1985; Belsky et al. 1993; Rosenthal and Kotanen 1994; Hobbs 1996). Tolerance to vertebrates also may often involve the ability to respond to environmental changes. Decreased competition and increased resources associated with intense grazing or browsing may promote regrowth, if plants are able to exploit these opportunities. For example, species with extensive near-surface root nets may have access to the nutrients in herbivore dung or urine; species with flexible growth may be able to exploit increased light levels. 
Again, these tend to be broad responses: effective resource acquisition often has direct benefits even in the absence of grazing.

Highly tolerant species may possess many of these characteristics. For example, the grass Puccinellia phryganodes is heavily grazed by Lesser Snow Geese in the central Canadian Arctic; grazing tolerance in this species is attributable to a suite of characters including a prostrate growth

form, highly plastic clonal growth, lack of dependence on sexual reproduction, a dense root net, flexible and continuous leaf production, and its ability to exploit nutrients contained in goose droppings (Cargill and Jefferies 1984a,b; Bazely and Jefferies 1989; Hik and Jefferies 1990; Hik et al. 1991). This grass also demonstrates that grazing tolerance can be a delicate balance: other species may displace Puccinellia if goose grazing is excluded (Bazely and Jefferies 1986), yet recent overgrazing near Snow Goose colonies (Iacobelli and Jefferies 1991; Srivastava and Jefferies 1995, 1996; Jano et al. 1998) provides an example of a system which has collapsed when herbivore pressure has exceeded plants' abilities to respond. Foraging is sustainable between these extremes, when the result can be increased primary production of this highly tolerant species, relative to that of ungrazed sites (Cargill and Jefferies 1984b; Hik and Jefferies 1990; Hik et al. 1991).

\section{Responses to invertebrates}

As with tolerance to vertebrate herbivory, growth-related characters like compensatory photosynthetic rates, flexible branching, and post-damage resource allocation patterns frequently may contribute to tolerance to invertebrate damage (Trumble et al. 1993; Rosenthal and Kotanen 1994; Stowe et al. 2000). However, the great diversity of types of damage inflicted by invertebrates (Bardner and Fletcher 1974; Strong et al. 1984; Mattson et al. 1988) suggests that interactions with 
mechanisms of tolerance also should be diverse. Even feeding on the same plant organ (e.g., folivory) may engender different plant responses, depending on the specific nature of damage. For example, photosynthetic enhancement in response to insect defoliation has been found in a wide variety of grasses, trees, forbs and shrubs in managed and natural systems. In contrast, studies which examined "selective feeders" such as leaf miners and suckers more commonly found reduced photosynthetic rates on a per unit area basis (Welter 1989). Similarly, the strong sectoriality of assimilate movement found in woody plants, among others, may either constrain or facilitate tolerance, depending on the plant part damaged and the type of herbivore (Obeso 1993; Marquis 1996). It appears likely that sectoriality reduces the ability of sap-sucking or galling insects to drain resources from entire plant, and hence may be a useful tolerance mechanism against some invertebrates. In an example of another isolation mechanism, some galled Solidago individuals show a marked increase in the tendency to detach the stressed ramet from the remainder of the clone, in what may be an adaptation to maximize fitness of the genetic individual (Abrahamson and Weis 1997). However, sectoriality and related isolation mechanisms may be of little value when entire ramets are removed by chewing insects or browsing mammals, or when they reduce the ability of plants to repair damaged ramets (Obeso 1993; Marquis 1996).

It is likely that tolerance to invertebrates includes a great variety of characters which have received little attention because of the scale at which they function. For example, the speed with which a puncture wound is sealed by surface waxes or other plant secretions could be extremely important in tolerating damage from cicadas in arid environments. Mesophyll cell size could be important in minimizing the collateral damage from feeding by leaf miners and some sucking insects. Studies with greater resolution at the scale at which most insects feed are likely to identify such tolerance mechanisms. 


\section{Cross-tolerance}

If mechanisms of tolerance differ between vertebrate vs. invertebrate herbivory, then these differences may lead to different consequences when plants experience multiple stresses. For example, if responses to vertebrates are nonspecific in nature, cross-tolerance (Strauss and Agrawal 1999) should be common: a plant tolerant to one vertebrate is likely to be tolerant to others, as well as to biomass reduction by many physical stresses. In contrast, since responses to invertebrates often are related to the specific type of damage, tolerance to one invertebrate frequently may be independent of tolerance to other herbivores (Strauss and Agarwal 1999).

Sufficient data do not yet exist to rigorously assess this hypothesis. Nonetheless, there is evidence that highly vertebrate-tolerant plants often may be cross-tolerant. Prairie grasses provide some of the best-known cases; for example, caespitose shortgrass steppe species in the American Great Plains (e.g., Bouteloua, Buchlöe) apparently are tolerant of a wide range of biological and physical stresses. These grasses formerly supported vast herds of bison, but now sustain equally numerous cattle, sheep, pronghorn, and prairie dogs, and tend to be replaced by other species if vertebrate grazing is suppressed (Whicker and Detling 1988a,b; Milchunas et al. 1989, 1990, 1998). Many prairie grasses also are highly tolerant of bulk tissue losses to drought and/or fire; indeed, these tolerances in early grasses may have led to tolerance of grazing by newly emerging guilds of ungulates (Stebbins 1981; Axelrod 1985; Coughenour 1985). Conversely, sensitivity to vertebrates may extend to multiple impacts as well. For example, many bunchgrasses are sensitive to grazing, and have been severely reduced in areas of the American intermountain west by livestock; these are species that occur in areas where large herds of bison were historically absent, and presumably they were not strongly selected for herbivore tolerance (Mack and Thompson 1982; Mack 1986; Milchunas et al. 1988; Mack 1989). Many of these species are also fire- 
sensitive, and also have suffered as a result of increased fire frequency associated with invasions of exotic grasses (D'Antonio and Vitousek 1992).

As discussed above, tolerance to invertebrate herbivory probably also frequently benefits from generalized growth responses, but additionally may demand mechanisms specific to a feeding type, and not necessarily linked to bulk tissue replacement. As a result, tolerance to one type of herbivore may be a poor predictor of tolerance to others; for example, meristem activation may confer tolerance to stem borers, but not necessarily to leaf chewers or seed parasitioids. Crosstolerance to functionally different insect herbivores does occur; for example, tolerance to folivory in Ipomoea purpurea is correlated with tolerance to apical meristem damage (Tiffin and Rauscher 1999). Despite this, numerous examples exist of plants which successfully tolerate one type of damage, but still are highly sensitive to certain other insect herbivores. Tolerance of prairie grasses to herbivory by vertebrates and to many folivorous insects does not extend to damage by root borers or outbreaking insect folivores (Watts et al. 1982; Milchunas et al. 1990; Tscharntke and Greiler 1995). As another example, root-boring moths of Lupinus arboreus cause significant mortality of plants; in contrast, folivores do not cause extensive mortality, though they do reduce seed production (Strong et al. 1995; Maron 1998). Finally, as discussed above, tolerance contributions from assimilate flow sectoriality and photosynthetic rate enhancement may be very different when the source of damage is sucking insects as compared with chewing insects (Welter 1989; Marquis 1996).

\section{Conclusion}

Plants may not "care" if their enemies have backbones, but they are significantly affected by traits which differ between vertebrates and invertebrates. Differences in the size, feeding styles, 
behaviour, and ecology of these groups result in important differences in temporal rates of damage, tissue specificity, spatial distribution of damage, and indirect effects of herbivory. Tolerating vertebrate herbivores is likely to require the ability to tolerate sporadic non-specific impacts. This can be achieved by broad responses promoting regrowth and resource acquisition, resulting in broad-spectrum tolerance. Tolerance to invertebrates also may be increased by such responses, but their damage tends to be both more diverse and more specific in nature. Tolerance to invertebrates is likely to require a corresponding range of responses linked to the specific nature of the damage; as a result, it may be harder for plants to achieve cross-tolerance. These results mirror and interact with patterns of plant defence: chemical and physical defences often vary greatly in effectiveness against different insects, while defences against vertebrates are rarely so species-specific (Fritz and Simms 1992). Insect and vertebrate herbivory are different syndromes with overlapping but different responses. 


\section{Acknowledgements}

The production of this manuscript was supported by an NSERC Research Grant and the University of Toronto (PMK), and by the Fogarty International Center of the National Institutes of Health (JPR). The manuscript was improved by comments from Tom Juenger, Tommy Lennartsson, Martha Weiss, Leslie Ambedian, and two anonymous reviewers. 


\section{References}

Abrahamson, W.G. and Weis, A.E. (1997) Evolutionary Ecology Across Three Trophic Levels:

Goldenrods, Gallmakers, and Natural Enemies. Princeton University Press, Princeton, New Jersey, USA.

Axelrod, D.I. (1985) Rise of the grassland biome, central North America. Bot. Rev. 51, 163-201.

Baldwin, I.T. and Preston, C.A. (1999) The eco-physiological complexity of plant responses to insect herbivores. Planta 208, 137-145.

Bardner, R. and Fletcher, K. (1974) Insect infestations and their effects on the growth and yield of field crops: a review. Bull. Entomol. Res. 64, 141-60.

Bazely, D.R. and Jefferies, R.L. (1986) Changes in the composition and standing crop of salt-marsh plant communities in response to the removal of a grazer. J. Ecol. 74, 693-706.

Bazely D.R. and Jefferies, R.L. (1989). Leaf and shoot demography of an Arctic stoloniferous grass, Puccinellia phryganodes, in response to grazing. J. Ecol. 77, 811-822.

Belsky, A.J., Carson, W.P., Jensen, C.L. and Fox, G.A. (1993) Overcompensation by plants: herbivore optimization or red herring? Evol. Ecol. 7, 109-121.

Bernays, E.A. and Chapman, R.F. (1994) Host-Plant Selection by Phytophagous Insects. Chapman and Hall, New York, New York, USA.

Borror, D.J., Triplehorn, C.A. and Johnson, N.F. (1989) An Introduction to the Study of Insects, 6th edn. Harcourt Brace, Fort Worth, Texas, USA.

Brown, D.G. (1994) Beetle folivory increases resource availability and alters plant invasion in monocultures of goldenrod. Ecology 75, 1673-1683.

Cargill, S.M. and Jefferies, R.L. (1984a) Nutrient limitation of primary production in a sub-arctic salt marsh. J. Appl. Ecol. 21, 657-668. 
Cargill, S.M. and Jefferies, R.L. (1984b) The effects of grazing by lesser Snow Geese on the vegetation of a subarctic salt-marsh. J. Appl. Ecol. 21, 669-686.

Coley, P.D. and Barone, J.A. (1996) Herbivory and plant defenses in tropical forests. Annu. Rev. Ecol. Syst. 27, 305-335.

Coughenour, M.B. (1985) Graminoid responses to grazing by larger herbivores: adaptations, exaptations, and interacting processes. Ann. Mo. Bot. Gard. 72, 852-863.

Crawley, M. (1983) Herbivory: the Dynamics of Animal-Plant Interactions. University of California Press, Berkeley, California, USA.

Crawley, M. (1989) The relative importance of vertebrate and invertebrate herbivores in plant population dynamics. In: Insect-Plant Interactions, volume I (E. A. Bernays, ed.), pp. 45-71. CRC Press, Boca Raton, Florida, USA.

Crawley, M. (1997) Plant-herbivore dynamics. In: Plant Ecology, 2nd edn. (M. Crawley, ed.), pp 401-474. Blackwell Science, Oxford, UK.

D'Antonio, C.M. and Vitousek, P.M. (1992) Biological invasions by exotic grasses, the grass/fire cycle, and global change. Annu. Rev. Ecol. Syst. 23, 63-87.

Detling, J.K. and Painter, E.L. (1983) Defoliation responses of western wheatgrass populations with diverse histories of prairie dog grazing. Oecologia 57, 65-71

Doak, D.F. (1992) Lifetime impacts of herbivory for a perennial plant. Ecology 73, 2086-2099.

Fay, P.A., Hartnett, D.C. and Knapp, A.K. (1996) Plant tolerance of gall-insect attack and gallinsect performance. Ecology 7, 521-534.

Flynn, J.L. and Reagan, T.E. (1984) Corn phenology in relation to natural and simulated infestations of the sugarcane borer (Lepidoptera: Pyralidae). J. Econ. Entomol. 77, 1524-1529. 
Fritz, R.S. and Simms, E.L. (eds) (1992) Plant Resistance to Herbivores and Pathogens: Ecology, Evolution, and Genetics. University of Chicago Press, Chicago, Illinois, USA.

Harper, J. (1977) Population Biology of Plants. Academic Press, London, UK.

Hendrix, S.D. (1988) Herbivory and its impacts on plant reproduction. In: Plant Reproductive

Ecology: Patterns and Strategies (J. Lovett Doust and L. Lovett Doust, eds), pp 246-263. Oxford University Press, New York, USA.

Hik, D.S. and Jefferies, R.L. (1990) Increases in the net above-ground primary production of a saltmarsh forage grass: a test of the predictions of the herbivore-optimization model. J. Ecol. 78, 180195.

Hik, D.S., Sadul, H.A. and Jefferies, R.L. (1991) Effects of the timing of multiple grazings by geese on net above-ground primary production of swards of Puccinellia phryganodes. J. Ecol. 79, 715-730.

Hobbs, N.T. (1996) Modification of ecosystems by ungulates. J. Wildl. Manage. 60, 695-713.

Hulme, P.E. (1996) Herbivores and the performance of grassland plants: a comparison of arthropod, mollusc and rodent herbivory. J. Ecol. 84, 43-51.

Iacobelli, A. and Jefferies, R.L. (1991) Inverse salinity gradients in coastal marshes and the death of Salix: the effects of grubbing by geese. J. Ecol. 79, 61-73.

Jano, A.P., Jefferies, R.L. and Rockwell, R.F. (1998) The detection of change by multitemporal analysis of LANDSAT data: the effects of goose foraging. J. Ecol. 86, 93-99.

Krupnick, G.A. and Weis, A.E. (1999) The effect of floral herbivory on male and female reproductive success in Isomeris arborea. Ecology 80, 135-149.

Letourneau, D.K. (1998). Ants, stem-borers, and fungal pathogens: experimental tests of a fitness advantage in Piper ant-plants. Ecology 79, 593-603. 
Louda, S.M., Keeler, K.H. and Holt, R.D. (1990) Herbivore influences on plant performance and competitive interactions. In: Perspectives on Plant Competition. (J.B. Grace and D. Tilman, eds), pp 413-444. Academic Press, San Diego, California, USA.

Mack, R.N. (1986) Plant invasions into the intermountain west. In: Ecology of Biological Invasions of North America and Hawaii. (H.A. Mooney and J.A. Drake, eds), pp. 191-213. Springer-Verlag, New York, New York, USA.

Mack, R.N. (1989) Temperate grasslands vulnerable to plant invasions: characteristics and consequences. In: Biological Invasions: A Global Perspective (J.A. Drake, H.A. Mooney, F. di Castri, R.H. Groves, F.J. Kruger, M. Rejmánek, and M. Williamson, eds), pp. 155-179. Wiley, Chichester, UK.

Mack, R.N. and Thompson, J.N. (1982) Evolution in steppe with few large, hooved mammals. Am. Nat. 119, 757-773.

Maron, J.L. (1998) Insect herbivory above- and belowground: individual and joint effects on plant fitness. Ecology 79, 1281-1293.

Maron, J.L. and Jefferies, R.L. (1999) Bush lupine mortality, altered resource availability, and alternative vegetation states. Ecology 80, 443-454.

Marquis, R.J. (1992) The selective impact of herbivores. In: Plant Resistance to Herbivores and Pathogens: Ecology, Evolution, and Genetics. (R.S. Fritz and E.L. Simms, eds), pp 301-325. University of Chicago Press, Chicago, Illinois, USA.

Marquis, R.J. (1996) Plant architecture, sectoriality and plant tolerance to herbivores. Vegetatio 127, 85-97.

McNaughton, S.J. (1979) Grazing as an optimization process: grass-ungulate relationships in the Serengeti. Am. Nat. 113, 691-703. 
McNaughton, S.J. (1984) Grazing lawns: animals in herds, plant form, and coevolution. Am. Nat. 124, 863-886.

Mattson, W.J. Lawrence, R.K., Haack, R.A., Herms, D.A. and Charles, P.-J. (1988) Defensive strategies of woody plants against different insect-feeding guilds in relation to plant ecological strategies and intimacy of association with insects. In: Mechanisms of Woody Plant Defenses Against Insects: Search for Pattern. (W.J. Mattson, J. Levieux and C. Bernard-Dagan, eds). pp. 355. Springer-Verlag, New York, New York, USA.

Milchunas D.G., Lauenroth, W.K. and Burke, I.C. (1998) Livestock grazing: animal and plant biodiversity of shortgrass steppe and the relationship to ecosystem function. Oikos 83, 65-74. Milchunas, D.G., Lauenroth, W.K., Chapman, P.L. and Kazempour, M.K. (1989) Effects of grazing, topography, and precipitation on the structure of a semiarid grassland. Vegetatio $\mathbf{8 0 , 1 1 -}$ 23.

Milchunas, D.G., Lauenroth, W.K., Chapman, P.L. and Kazempour, M.K. (1990) Community attributes along a perturbation gradient in a shortgrass steppe. J. Veg. Sci. 1, 375-384.

Milchunas, D.G., Sala, O.E. and Lauenroth, WK (1988) A generalized model of the effects of grazing by large herbivores on grassland community structure. Am. Nat. 132, 87-106.

Nyvall, R.F. (1989) Field Crop Diseases Handbook (2nd edn.).Van Nostrand Reinhold, New York, New York, USA.

Obeso, J.R. (1993) Does defoliation affect reproductive output in herbaceous perennials and woody plants in different ways? Funct. Ecol. 7, 150-155.

Painter, R. (1958) Resistance of plants to insects. Annu. Rev. Entomol. 3, 267-290.

Pedigo, L.P., Hutchins, S.H. and Higley, L.G. (1986) Economic injury levels in theory and practice. Ann. Rev. Entomol. 31, 341-368. 
Rosenthal, J.P. and Kotanen, P.M. (1994) Terrestrial plant tolerance to herbivory. Trends Ecol. Evol. 9, 117-157.

Rosenthal, J.P. and Welter, S.C. (1995) Tolerance to a stemboring caterpillar in architecturally distinct maizes and wild relatives. Oecologia 102, 146-155.

Srivastava, D.S. and Jefferies, R.L. (1995) Mosaics of vegetation and soil salinity: a consequence of goose foraging in an arctic salt marsh. Can. J. Bot. 74, 75-83.

Srivastava, D.S. and Jefferies, R.L. (1996) A positive feedback: herbivory, plant growth, salinity and the desertification of an arctic salt marsh. J. Ecol. 84, 31-42.

Stebbins, G.L. (1981) Coevolution of grasses and herbivores. Ann. Mo. Bot. Gard. 68, 75-86.

Stowe, K.A., Marquis, R.J., Hochwender, C.G. and Simms, E.L. (2000). The evolutionary ecology of tolerance to consumer damage. Annu. Rev. Ecol. Syst. 31, 565-595

Strauss, S.Y. and Agarwal, A.A. (1999) The ecology and evolution of plant tolerance to herbivory. Trends Ecol. Evol. 14, 179-185.

Strong, D.R., Lawton, J.H. and Southwood, R. (1984) Insects on Plants. Harvard University Press, Cambridge, Massachusetts, USA.

Strong, D.R., Maron, J.L., Connors, P.G., Whipple, A., Harrison, S. and Jefferies, R.L. (1995) High mortality, fluctuation in numbers, and heavy subterranean insect herbivory in bush lupine, Lupinus arboreus. Oecologia 104, 85-92.

Throop, H.L. and Fay, P.A. (1999) Effects of fire, browsers and gallers on New Jersey Tea (Ceanothus herbaceus) growth and reproduction. Am. Midl. Nat. 141, 51-58.

Tiffin, P. and Inouye, B.D. (2000) Measuring tolerance to herbivory: accuracy and precision of estimates made using natural versus imposed damage. Evolution 54, 1024-1029. 
Tiffin, P. and Rausher, M.D. (1999) Genetic constraints and selection acting on tolerance to herbivory in the common morning glory Ipomoea purpurea. Am. Nat. 154, 700-716.

Trumble, J.T., Kolodny-Hirsch, D.M. and Ting, I.P. (1993) Plant compensation for arthropod herbivory. Ann. Rev. Entomol. 38, 93-119.

Tscharntke, T. and Greiler, H.J. (1995) Insect communities, grasses, and grasslands. Annu. Rev. Entomol. 40, 535-58.

Vallentine, J.F. (1990) Grazing Management. Academic Press, San Diego, California, USA. van der Meijden, E., Wijn, M. and Verkaar, H.J. (1988) Defence and regrowth, alternative plant strategies in the struggle against herbivores. Oikos 51, 355-363

Varnamkhasti, A.S., Milchunas, D.G., Lauenroth, W.K. and Goetz, H. (1995) Production and rain use efficiency in short-grass steppe: grazing history, defoliation and water resource. J. Veg. Sci. 6, 787-796.

Watts, J.G., Huddleston, E.W. and Owens, J.C. (1982) Rangeland entomology. Annu. Rev. Entomol. 27, 283-311.

Welter, S.C. 1989 Arthropod impact on plant gas exchange. In: Plant-Insect Interactions, volume I (E.A. Bernays, ed.), pp 135-150. CRC Press, Boca Raton, Florida, USA.

Whicker, A.D. and Detling, J.K. (1988a) Ecological consequences of prairie dog disturbances. Bioscience 38, 778-795.

Whicker, A.D. and Detling, J.K. (1988b) Modification of vegetation structure and ecosystem processes by North American grassland mammals. In: Plant Form and Vegetation Structure (M.J.A. Werger, P.J.M. van der Aart, H.J. During and J.T.A. Verhoeven, eds), pp 301-316. SPB Academic, The Hague, the Netherlands. 
Table 1. Proposed features affecting tolerance to vertebrate and invertebrate herbivores.

\begin{tabular}{|c|c|c|}
\hline & Invertebrate & Vertebrate \\
\hline Examples of feeding & $\begin{array}{l}\text { Chewing of leaves, root tips, ovules, } \\
\text { pollen, meristems; mining and rasping of } \\
\text { epidermis; sucking of cell sap, phloem } \\
\text { assimilate, xylem fluids; boring of bark, } \\
\text { stems, roots; gall forming on stems, leaves. }\end{array}$ & $\begin{array}{l}\text { Grazing, browsing, } \\
\text { root feeding }\end{array}$ \\
\hline $\begin{array}{l}\text { Herbivore body size and } \\
\text { bite size relative to plant } \\
\text { size }\end{array}$ & Small & Large \\
\hline $\begin{array}{l}\text { Duration of herbivore } \\
\text { attacks }\end{array}$ & Long & Short \\
\hline $\begin{array}{l}\text { Rate of damage during an } \\
\text { attack }\end{array}$ & Low & High \\
\hline Diversity of damage types & High & Low \\
\hline $\begin{array}{l}\text { Scale of patchiness of } \\
\text { damage }\end{array}$ & $\begin{array}{l}\text { Small for sedentary species, larger for } \\
\text { mobile species }\end{array}$ & Larger or multiscale \\
\hline Indirect effects & Uncommon, often negative & $\begin{array}{l}\text { Common, can be } \\
\text { positive }\end{array}$ \\
\hline Tolerance affected by & Depends on damage type & Regrowth ability \\
\hline Evolutionary consequences & $\begin{array}{l}\text { Selection for specific tissue repair, } \\
\text { replacement, isolation, or accommodation }\end{array}$ & $\begin{array}{l}\text { Selection for } \\
\text { generalized growth } \\
\text { responses }\end{array}$ \\
\hline Exceptions & $\begin{array}{l}\text { Indiscriminate grazers (grasshoppers, } \\
\text { armyworms); insects attacking seedlings }\end{array}$ & $\begin{array}{l}\text { Selective seed feeders, } \\
\text { pollinators }\end{array}$ \\
\hline
\end{tabular}

